\title{
PROFESSIONAL SELF-CONSCIOUSNESS OF STUDENTS OF A PEDAGOGICAL UNIVERSITY: RESULTS OF THE RESEARCH
}

\author{
Tatyana Bugaychuk \\ Yaroslavl State Pedagogical University named after K.D. Ushinsky, \\ Russian Federation \\ Olga Koryakovtseva \\ Yaroslavl State Pedagogical University named after K.D. Ushinsky, \\ Russian Federation \\ Olga Rubleva \\ Vyatka State University, Russian Federation \\ Galina Burakova \\ Yaroslavl State Pedagogical University named after K.D. Ushinsky, \\ Russian Federation
}

\begin{abstract}
The article is devoted to the study of the formation of professional self-consciousness of a student - a future teacher, with an emphasis on the features of professional self-esteem as an element of professional self-consciousness. The data obtained in the article using the methods of studying professional self-esteem and professional self-knowledge allow us to pay attention to the complex procedure of entering the profession by students of a pedagogical university, passing through the crises of vocational training at 2 and 5 courses, $3 r d$ and 4 th year students are completely ready to study, work, accumulate knowledge and develop in a wider professional sense, they have a focus on self-development. The dynamics of development of students' ideas about themselves at different stages of studying at university are shown, the emphasis is on the features of formation of professional self-esteem of future teachers. The study opens up significant prospects for advanced training and improving the quality of students' training, taking into account the characteristics of the development of their professional self-consciousness.
\end{abstract}

Keywords: professional self-esteem of students, professional formation of the person, professional self-consciousness, students of a pedagogical university.

\section{Introduction}

For many decades, the need to consider the student as a subject of education has been discussed in university pedagogy. But the realities of life outside the university and inside it were such that this position was declarative for a long time. However, the training of professional teachers is dictated by the fundamental 
Bugaychuk et al., 2020. Professional Self-Consciousness of Students of a Pedagogical University: Results of the Research

changes taking place in Russian education (Koryakovtseva \& Bugaychuk, 2014). And an important component of the initial stage of professionalization is the period of studying at university, where the future specialist receives the necessary knowledge and skills, gets acquainted with senior colleagues, and clarifies his/her initial idea of the activity to which he/she decided to devote himself/herself when entering this educational institution. The period of studying at university is significant in the process of establishing professional self-consciousness (professional identity and professional self-esteem).

According to G.Yu. Lyubimova, in addition to the transfer of knowledge and skills (informing), an important task of university education is also the formation of the professional personality and the assistance in his/her identification with the profession (Lyubimova \& Evsevicheva, 2011).

N.N. Balitskaya notes the relevance of studying the formation of the professional self-consciousness of students of pedagogical universities, focusing on the fact that in modern conditions social development can only be carried out by the creatively thinking, active and fully developed personality ... That is why special attention should be paid to professional training of the future teacher, to form his/her self-consciousness and professional self-identity (Balitskaya, 1995).

If we talk about the dialogical unity of the educational activity and processes of personal and professional self-determination when studying at university, relying on the works of V.P. Zinchenko (Zinchenko \& Morgunov, 1994), T.M. Buyakas (Buyakas, 2018), it should be noted that the process of acquiring "values-for-me" in the framework of professional education can characterize university students' professional self-consciousness formation. In this regard, it is obvious that the skill of teaching is largely related to the ability to "settle" the internal dialogue into student consciousness.

The above mentioned works by Russian psychologists emphasize the importance of the process of professional self-consciousness and self-esteem during the period of studying at university. Important results obtained in these studies allow us to form certain ideas about the laws governing professional selfesteem formation. At the same time, there are some issues that remain unclear; they are related to the stages of professional self-consciousness formation in general and during the period of studying at university, and to professional selfconsciousness crises that arise in the process of learning. There are unstudied factors that influence the formation of professional self-esteem at the stage of training at a pedagogical university, as well as the question of the ratio of parameters that determine the formation of professional self-esteem.

The purpose of this article, we define in the next - the identification of the dynamics of professional self-esteem as an element of professional consciousness of students of pedagogical high school to determine the characteristics of their professionalization. 


\section{Theoretical basis of the study}

Having analyzed the main researches on the studied problem, it is worth discussing the following standpoints. Professional self-consciousness is the leading characteristic of the subject of labor and the criterion for professional development of the individual (Povarenkov, 2012), it indicates the degree of acceptance of the chosen professional activity as a means of self-realization and development, as well as the degree of recognition of oneself as the professional (Bugaychuk, 2015). A.K. Markova defines professional self-consciousness as a complex of representations of a person about himself as a professional, this is a holistic image of himself as a professional, a system of relations and attitudes towards himself as a professional (Markova, 1996).

The professional self-consciousness includes three structural components: cognitive, affective and the behavioral component.

The first component of the professional self-consciousness structure characterizes the person's attitude to himself/herself as a future and acting professional. In this case, the real or predicted professional self-esteem are meant. A similar point of view on the professional self-consciousness models the selfesteem process, which is fixed in the framework of the cognitive approach to the development of self-consciousness; therefore we define this component as cognitive. Indeed, the basis of this approach is the idea of the professional selfconsciousness formation as a result of projecting the real professional self-esteem of the subject onto the ideal, with the subsequent restructuring of the first. The proximity between the ideal and real self-esteems accepted by the subject is the basis for acquiring the sense of professional self-consciousness and the basis for its subsequent development. As L.M. Mitina notes, professional selfconsciousness as the basis of the self-esteem, which in its turn is the basis of professional development of the specialist, determines the formation of the professional self-consciousness (Mitina, 2018).

The issue of professional self-consciousness and self-esteem is inextricably linked with the problem of the teacher's self-determination. So, P.A. Shavir believes that the degree of formation of professional self-consciousness of a university graduate can serve as an indicator of the success and completeness of his professional self-determination (Shavir, 1981). Therefore, taking into account the features of professional self-consciousness, the search for reserves for its improvement is a prerequisite for the success of all career guidance work in a university. According to K.A. Abulkhanova, in professional self-consciousness, the personality represents itself both as an object in a certain socio-professional system and as its subject (Abulkhanova, 2009). This is due, firstly, to the awareness of the correspondence of one's personal capabilities to professional 
Bugaychuk et al., 2020. Professional Self-Consciousness of Students of a Pedagogical University: Results of the Research

requirements and tasks, secondly, to reflection, satisfaction, success and, thirdly, to social approval.

It should also be noted that as professionalism grows, professional selfconsciousness changes. It expands due to the inclusion of new features of a developed profession, which imposes new requirements on a professional person, and the criteria for evaluating oneself as a professional change.

The professional self-esteem is an assessment of oneself as a subject of activity, expressed in assessing one's professional and pedagogical level (the formation of skills), in the level of competence (knowledge system), in assessing one's personal qualities in connection with the ideal image «I am a professional» (Rean \& Demyanchuk, 2016)

\section{Materials and methods}

The formation of professional self-consciousness is primarily related to the development of the corresponding system of the professional activity, including its professional component (goals, programs, control, regulation) and structural components (motives, abilities, experience) (Koryakovtseva \& Bugaychuk, 2017). The following can be considered as parameter for the development of selfconsciousness: qualitative and quantitative feature of professional self-esteem ("Acceptance of oneself as a professional") (Bugaychuk, 2013). Self-esteem plays a leading role in the study of self-consciousness problems.

Students were offered two methods aimed at studying professional selfconsciousness and its component - professional self-esteem. Firstly, the diagnosis was carried out according to the methodology of the Dembo-Rubinstein selfesteems study. In our work, we use a modified version of this technique. To carry out its modification, an expert group of five people was created, which compiled a list of professionally important qualities that affect professional activities. Then this technique was tested on students of the specialty "Psychology" consisting of 30 people. The methodology used by us is based on a direct assessment by subjects of a number of professional qualities, such as "mental capabilities", "selfconfidence", "authority among peers", "communication skills", "organizing skills", "industriousness" and "activity". Students were asked on vertical lines to mark with certain signs the level of development of currently offered professionally important qualities (indicator of professional self-esteem, "I am a professional") and the level of claims (ideal of the image "I am a professional"), that is, the level of development these same professionally important qualities that would satisfy them.

The second method that we use in the study is the method for diagnosing professional self-knowledge of future teachers (the author's method is 
N.G. Rukavishnikova). This technique is aimed at studying the attitude of students to teaching activities and themselves as a future teacher (Rukavishnikova, 1999).

The results obtained in the study were processed using the Statistika computer program; the Mann-Whitney U-test was used to assess statistical significance.

The study involved 1-5-year students of the pedagogical university (double degree Bachelor's programme, specializations of the Faculty of Physics and Mathematics and the Faculty of Social Management). The sample consisted of 103 students, in which the subsample of the first-year students -29 people, the subsample of the second-year students -17 people, the subsample of the thirdyear students -20 people, the subsample of the fourth-year students -20 people, the subsample of the fifth-year students -17 people.

\section{Results and discussion}

We highlight the main features of formation of professional self-esteem among students of a pedagogical university in each year of study.

After analyzing the data obtained using the Dembo-Rubinstein methodology and comparing the average indicators of professional self-esteem between courses using the Mann-Whitney U-test, we obtained the following results (Table 1).

\section{Table 1 The average values of professional self-esteem 1st to 5th courses on method} Dembo-Rubinstein

\begin{tabular}{|l|c|c|c|c|c|}
\hline Professionally important qualities & 1 st year & $2^{\text {nd }}$ year & $3^{\text {rd }}$ year & $4^{\text {th }}$ year & $5^{\text {th }}$ year \\
\hline S: Mental capabilities & 59,50 & 62,70 & 68,63 & 64,79 & 54,00 \\
\hline P: Mental capabilities & 84,67 & 84,40 & 88,40 & 91,38 & 84,65 \\
\hline S: Self confidence & 56,63 & 64,30 & 64,30 & 67,34 & 54,90 \\
\hline P: Self confidence & 83,00 & 83,67 & 87,77 & 90,41 & 79,05 \\
\hline S: Authority among peers & 63,20 & 68,20 & 65,07 & 66,38 & 54,45 \\
\hline P: Authority among peers & 80,63 & 82,27 & 80,07 & 85,21 & 71,35 \\
\hline S: Communication skills & 60,63 & 63,93 & 72,50 & 74,52 & 49,50 \\
\hline P: Communication skills & 82,20 & 83,33 & 88,53 & 88,10 & 78,50 \\
\hline S: Organizing skills & 60,87 & 58,10 & 59,87 & 65,69 & 52,30 \\
\hline P: Organizing skills & 78,53 & 79,43 & 80,80 & 83,90 & 87,60 \\
\hline S: Industriousness & 55,57 & 61,20 & 65,80 & 65,14 & 54,80 \\
\hline P: Industriousness & 76,33 & 79,20 & 84,63 & 86,38 & 82,05 \\
\hline S: Activity & 62,33 & 60,87 & 66,47 & 67,28 & 51,50 \\
\hline P: Activity & 80,77 & 80,33 & 87,87 & 89,66 & 76,60 \\
\hline Self-esteem coefficient & 0,59 & 0,58 & 0,60 & 0,60 & 0,44 \\
\hline
\end{tabular}

$S$-professional self-esteem, "I am a professional" at the moment

$P$ - level of aspiration, the ideal image of "I - professional" 
Bugaychuk et al., 2020. Professional Self-Consciousness of Students of a Pedagogical University: Results of the Research

According to table 1, the quality "self-confidence" is most significantly expressed among fourth-year students - 67.34 and in the same course the biggest aspiration for this quality is 90.41 . We assume that this is due to the students' practical experience at school and studying most of the disciplines of the psychological and pedagogical module, which gives them confidence and a desire to improve their knowledge.

This trend is also noted for the quality "activity", which is most significantly expressed among fourth-year students -67.28 and in the same course the biggest aspiration for this quality is 89.66 .

Perhaps the self-confidence of the 4th-year students is also associated with the development of their (self-esteem) communication and organizing abilities, since both communication and organizing skills are significantly expressed among fourth-year students, they are 74.52 and 65.69, respectively.

At the same time, the third-year students have the highest aspiration in communication skills -88.53 , and the fifth-year students in organizing skills (87.60). Here we see signs of a crisis in the development of professional selfawareness and a decrease in professional self-esteem, because these qualities underlie the professional activities of the teacher and are considered to be professionally important.

The quality "authority among peers" is most significantly expressed among 2nd year students -68.20 . At the same time, the fourth year students have the biggest aspiration for this quality - 85.21. In our opinion, 2nd year students evaluate themselves from the point of view of educational activity - the period of adaptation is over, actually personal and educational results have appeared. Students of the 4th year are more focused on professional activities that will increase their credibility, their position is striving to finish their studies and have independent activities.

The quality "industriousness" is most significantly expressed among thirdyear students -65.80 . And the biggest aspiration for this quality among students of the 4 th year is 86.38 .

As we see from the diagnostic results, the peak of educational and professional development in terms of assessing oneself as a future professional is 4th year of study, when students receive the necessary set of knowledge and practical experience, they see themselves as active, organized, sociable, confident, it is important to note that they evaluate themselves from the point of view of not a professional, but a student, since they still see that they lack authority and industriousness. But 5th year students rated themselves as future professionals, and here we see a crisis of vocational training, manifested in the underestimation of their professionally important qualities and the desire to develop organizational skills. Our findings are confirmed statistically. Self-esteem coefficients are most significantly expressed in the 3rd and 4th years -0.60 each. And the lowest self- 
esteem coefficient was found in students of the 5 th year -0.44 . It is possible that the 5th year students are anxious before entering an adult professional life.

As for the 1 st and 2 nd courses, they rated themselves higher, which probably indicates a high level of self-esteem in connection with entering the university.

Students of the 3rd and 4th courses have the highest self-esteem indicators, we can explain this by the fact that these students are oriented towards solving educational problems, they are ready to learn, work, and accumulate knowledge.

Let us turn to the results of the second methodology. From the data obtained on the methodology for diagnosing professional self-knowledge of future teachers, we found that in fifth-year students, vocational training begins to lose personal meaning and significance, which is manifested in dissatisfaction with their professional choice and unwillingness to continue the professional path of the teacher. The second year of study is also characterized by a decline in indicators of professional self-knowledge. If in the 1st year $86.6 \%$ of students are satisfied with their professional choice, then in the 2nd year they are $52.9 \%$, in the 3 rd $-90.9 \%$, in the 4 th year $-80 \%$, and in the 5 th year $-58.8 \%$. The obtained data allow us to conclude that first-year students have high self-esteem in connection with entering the university, their expectations and ideas about the teaching profession are still somewhat unrealistic. Among $3^{\text {rd }}$ and $4^{\text {th }}$ year students, the number of people satisfied with their professional choice is growing, which is possibly due to their success in teaching and in teaching practice. The number of these students among the $2^{\text {nd }}$ and $5^{\text {th }}$ courses is decreasing, which probably indicates the disappointment of the $2^{\text {nd }}$ year students in the process of studying at the university, and the 5th year students - in their ideas about the teaching profession and expectations from it.

If in the 1 st year $50 \%$ of students say that they will work as a teacher, then in the $2^{\text {nd }}$ year they are $35.2 \%$, in the $3^{\text {rd }}$ year this number increases to $86.3 \%$, in the $4^{\text {th }}$ year it is $88 \%$, and in the $5^{\text {th }}$ year this number is reduced to $5.8 \%$. The largest number of people claiming that they will work as a teacher is observed among students of the $3^{\text {rd }}$ and $4^{\text {th }}$ years, which is possibly due to their success in educational and professional activities. According to the number of students who agree with this statement, in the first course they are exactly the half, which probably indicates that they are not ready to think about professional activities after graduation. The smallest number of students claiming that they will work as a teacher is among the $5^{\text {th }}$ year students. We assume that this is due to insufficient knowledge of the essential features of the pedagogical profession, primarily to a lack of understanding of its motivational potential, i.e. opportunities to meet the basic needs of the individual: in communication, cognition, social recognition, self-esteem, self-realization in creativity.

A positive attitude towards oneself as a subject of pedagogical activity is not characteristic of all students. In particular, while in the $1^{\text {st }}$ year $93.3 \%$ of students 
Bugaychuk et al., 2020. Professional Self-Consciousness of Students of a Pedagogical University: Results of the Research

believe that they can become a good teacher, in the $2^{\text {nd }}$ year they are $64.7 \%$, in the 3rd $-90.9 \%$, in the 4 th year $-88 \%$, and in the $5^{\text {th }}$ year this number is reduced to $17.6 \%$. Moreover, $53.3 \%$ of the 1 st year students believe that they have the qualities necessary for the successful work as a teacher, in the $2^{\text {nd }}$ year this number is reduced to $35.7 \%$, in the $3^{\text {rd }}$ and $4^{\text {th }}$ courses it is $81.8 \%$, and in the $5^{\text {th }}$ year this number is $23.5 \%$. The obtained data can be explained by the fact that the $1^{\text {st }}$ year students have a professional self-esteem that is inflated due to high self-esteem after entering the university. Students of the $3^{\text {rd }}$ and $4^{\text {th }}$ years have success in vocational training and they are very confident in themselves. But the smallest number of students who believe that they can become good teachers is observed among students of the $2^{\text {nd }}$ and $5^{\text {th }}$ courses. It is possible that in the $2^{\text {nd }}$ year students feel disappointment in the process of studying at the university and doubts about the correct choice of their professional path. And for students of the 5th year, this is due to anxiety about uncertainty of early professional activity and self-doubt as a professional.

According to the parameter "the desire for professional self-knowledge and professional development", we can distinguish the following features of students' professional self-knowledge: $96.6 \%$ of the 1 st year students are constantly striving for growth, self-improvement, in the 2 nd year this number is reduced to $88.2 \%$, among the $3^{\text {rd }}$ and $4^{\text {th }}$ year students this number is $100 \%$, and the number of the $5^{\text {th }}$ year students is reduced to $76.4 \% .83 .3 \%$ of the $1^{\text {st }}$ year students are constantly striving to advance on the path of mastering the profession of the teacher, in the 2 nd year this number is reduced to $47 \%$, among the $3^{\text {rd }}$ and $4^{\text {th }}$ year students this number is $100 \%$ again, and the number of students of the $5^{\text {th }}$ year decreases to $17.6 \%$. It is possible that the results can be explained by the fact that the $1^{\text {st }}$ year students, although they still do not have sufficient knowledge, skills, still strive to acquire them. The $3^{\text {rd }}$ and $4^{\text {th }}$ year students are completely ready to study, work, accumulate knowledge and develop in a wider professional sense, they have a focus on self-development. Students of the $2^{\text {nd }}$ and $5^{\text {th }}$ courses are again experiencing a crisis in the manifestation of professional self-knowledge. The $2^{\text {nd }}$ year students may be somewhat disappointed by their future profession or their learning process. And for students of the 5th year, this may be due to insecurity in their professional competence and upcoming professional activities.

\section{Conclusions}

It should be noted that the development of the identity of the future teacher is determined by the influence of two factors. First of all, in the process of training, students of a pedagogical university assimilate professional values in terms of the disciplines of the psychological and pedagogical cycle. Through comprehension of these concepts, professionally significant properties and peculiarities of one's 
self are realized. The second factor in the formation of the self-consciousness of future teachers is the pedagogical activity itself during the period of teaching practice, during which professionally important properties and characteristics of the future teacher are manifested, clarified for others and for the student himself/herself (Upeniece, Arnis, Korjakovceva, \& Bugajchuk, 2017).

The empirical data obtained in the work on the process of formation of professional self-consciousness of students of a pedagogical university, namely, the identified crisis periods of vocational training in students of 2 and 5 courses and the positive dynamics in students of 1,3 and especially 4 courses, allow to improve the training of teachers, increase the effectiveness of psychological help future teachers in solving the problems of psychological readiness for professional activity. This can be ensured during the methodological support of the educational process through the use of research results in special courses on professional selfdevelopment of the personality.

In our opinion, the specific features of the formation of the professional selfconsciousness and self-esteem of students should be taken into account when drawing up curricula and educational programs in higher educational institutions for successful formation of professional self-consciousness in the period of professional training.

\section{Summary}

The transformation of the individual into the professional and the achievement of professional self-consciousness belongs to the category of fundamental scientific problems, the enduring relevance of which is determined by the high importance of professional activity for society and for each individual.

Professional self-consciousness includes three components of the structure: cognitive, affective and the behavioral component. As a result of the study, it was determined that, due to the self-esteem play the leading role, while others are secondary. Despite the predominance of individual components, the presence of conflict relations between them, they act as holistic, the function of which is to help the person understand the problems of his/her professional formation and implementation.

It should be noted that the training of the modern specialist in higher education institution should be focused on the formation of his/her educational and professional, and then professional self-consciousness.

\section{References}

Abulkhanova, K.A. (2009). Consciousness as a person's life ability. Psychological journal, 1. 32-43.

Balitskaya, N.N. (1995). Formation of self-identity of future teachers in the process of training. Voprosy psikhologii. 1, 25-29.

Bugaychuk, T.V. (2015). Dynamics of development of professional identity of students of the pedagogical university: psychosemantic analysis. Systemogenesis of educational and 
Bugaychuk et al., 2020. Professional Self-Consciousness of Students of a Pedagogical University:

Results of the Research

professional activities, 141-143.

Bugaychuk, T.V. (2013). Characterization of the concept and structure of identity from the position of a system-genetic approach. Systemogenesis of educational and professional activities, 114-117.

Buyakas, T.M. (2018). Systemic reflection as a condition for the subjectivity of the process of professionalization. Self-realization of personality in the modern world, 36-44.

Zinchenko, V.P., \& Morgunov, Ye.B. (1994). The man developing. Essays on Russian psychology. M. Trivola.

Koryakovtseva, O.A., \& Bugaychuk, T.V. (2017). On the problem of developing the personnel potential of the regional education system in the context of the implementation of the professional standard. Actual problems of psychology and pedagogy in modern education, 157-159.

Koryakovtseva, O.A., \& Bugaychuk, T.V. (2014). The specifics of the professional development of the teacher at the present stage of development of higher education. High school at the present stage: problems of teaching and learning, 70-74.

Lyubimova, G.YU., \& Evsevicheva, I.V. (2011). Self-evaluation in the professional sphere. Psychology and Psychotechnics. 9, 49-59.

Markova, A.K. (1996). Psychology of professionalism. M.: Knowledge.

Mitina, L.M. (2018). Personal and professional development of a teacher: strategies, resources, risks. M.; St. Petersburg: Nestor-Istoriya.

Povarenkov, YU.P. (2012). Problems of psychology of professional formation of personality Saratov.

Rean, A.A., \& Demyanchuk, R.V. (2016). Methodological bases of psychological support of a teacher at different stages of its professional and personalization. Russian Psychological Journal, 13(1), 85-93.

Rukavishnikova, N.G. (1999). Professional self-knowledge of students of a pedagogical university. $\mathrm{M}$.

Shavir, P.A. (1981). Psychology of professional self-determination in early youth. M.: Pedagogy.

Upeniece, I., Arnis, V., Korjakovceva, O.A., \& Bugajchuk, T.V. (2017). Povyshenie professional'noj kompetentnosti pedagogov $\mathrm{v}$ oblasti formirovanija grazhdanskoj identichnosti obuchajushhihsja. Education reform in comprehensive school: education content research and implementation problems, 44-53. 